\title{
Corrigendum
}

\section{Cell death induced by dexamethasone in lymphoid leukemia is mediated through initiation of autophagy}

E Laane, K Pokrovskaja Tamm, E Buentke, K Ito, P Kharaziha, J Oscarsson, M Corcoran, A-C Björklund, K Hultenby, J Lundin, M Heyman, S Söderhäll, J Mazur, A Porwit, PP Pandolfi, B Zhivotovsky, T Panaretakis and D Grandér

Cell Death and Differentiation (2009) 16, 1071; doi:10.1038/cdd.2009.64

Correction to: Cell Death and Differentiation (2009) 16, 1018-1029; doi:10.1038/cdd.2009.46; published online 24 April 2009
Since the publication of their paper, the authors have noticed that the name of the fifth author was published incorrectly. The correct author list is shown above.

The authors apologize for any inconvenience caused. 